\title{
Kant, Xunzi and the Artificiality of Manners
}

\author{
Anja BERNINGER*
}

\begin{abstract}
Both Chinese and Western philosophers have argued for the ethical importance of manners. Their approaches are sometimes criticized on the grounds that manners are artificial. I compare Xunzi's and Kant's responses to this claim, and discuss the relevance of both positions for the development of a theory of manners. I show that there is no single artificiality claim, but rather four different claims: the claim that polite behavior lacks spontaneity, the claim that it is insincere, the claim that it goes against human nature, and the claim that it is arbitrary. While Kant is mainly concerned with the insincerity claim, Xunzi focusses on the claim that manners are arbitrary rules. Because of their different understandings of the function of manners both authors only provide a partial answer to the artificiality claim. To arrive at a full account of manners both perspectives must be combined.
\end{abstract}

Keywords: Xunzi, Kant, manners, politeness, artificiality

\section{Kant, Xunzi in izumetničenost pravil vedênja}

\section{Izvleček}

Tako kitajski kot zahodni filozofi so poudarjali etični pomen pravil vedênja, četudi so jih pogosto kritizirali zaradi njihove umetne narave. Avtorica primerja Xunzijevo in Kantovo stališče o tem problemu in ovrednoti pomen obeh pozicij za razvoj teorije vedênja. Pokaže, da stališče o izumetničenosti vedenjskih pravil ni samo eno, temveč gre za štiri različna stališča: pomanjkanje spontanosti, neiskrenost, nasprotje s človeško naravo ter arbitrarnost. Medtem ko se Kant v glavnem ukvarja s predpostavko neiskrenosti, se Xunzi bolj osredotoča na problematiko arbitrarnosti vedenjskih pravil. Zaradi različnega razumevanja funkcije pravil vedênja vsak od njiju izdela samo delne rešitve problema izumetničenosti. Ce pa želimo izdelati celovitejšo teorijo vedênja, je treba kombinirati obe perspektivi.

Ključne besede: Xunzi, Kant, vedênje, vljudnost, izumetničenost

Anja BERNINGER, Akademische Rätin/Lecturer;

Department of Philosophy, University of Stuttgart, Germany.

anja.berninger[at]philo.uni-stuttgart.de.

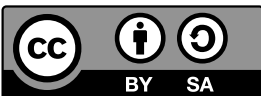




\section{Introduction}

Both Western and Chinese theorists have argued that manners have ethical importance (some recent examples are Buss 1999; Olberding 2016; Stohr 2012). In their view, politeness is not just a matter of convention, and thus we should not act politely simply because "that's what people do". Nor is well-mannered behavior merely of instrumental value. Rather, according to these thinkers, acting in a well-behaved manner is an important part of a good life.

Politeness is not a naturally given quality. Even though manners are not just a matter of mere convention, well-mannered behavior generally involves following certain man-made rules. Politeness thus requires us to acquire certain affective and action dispositions that are not always in line with our innate inclinations. These and similar aspects of manners have led critics to claim that manners are artificial.

In this paper I will explore two responses to this claim, one given by Kant and the other by Xunzi. In spite of the temporal and cultural distance between these two philosophers, their approaches to manners display some striking similarities. Both believe that manners and politeness can transform people for the better, and both are concerned about the claim that manners are artificial. Nevertheless, a close examination of their arguments shows that they discuss artificiality in slightly different senses. As I will show, this difference is a natural result of the overall function that they assign to well-mannered behavior. While Kant stresses that there is a communicative function inherent in manners, Xunzi is primarily concerned with what one can call the ordering function of manners.

These differences are instructive for those interested in systematic questions concerning the status of manners within ethical theory. We prima facie have reason to think that the artificiality claim poses a challenge to the belief that manners should be accorded ethical relevance. Both Kant and Xunzi respond to part of this challenge, but because of their respective takes on the function of manners each leaves out one central aspect. I will briefly suggest that this problem can be remedied by accepting that manners do not have a single function, but rather a row of different functions.

I will start off by first analyzing the term "artificial". I will show that we can differentiate four meanings, each of which can be used as the basis of a slightly different attack against the claim that manners are ethically relevant. I will then go on to explore both Kant's and Xunzi's positions on manners in detail and discuss which of these artificiality arguments they pick up, how they respond to them, and how this fits in with their overall theory. At the end of the paper I will then come back to the question of what this means for a systematic perspective on manners. 


\section{Unpacking the Artificiality Claim}

In a recent article on manners in the Xunzi, Amy Olberding highlights both the importance of the criticism that manners are in some sense artificial, and the diverse forms that this claim can take. She describes "artificiality" as a "catch-all term embracing a host of sins and ills associated with etiquette" and then claims:

For example, practicing etiquette may oblige social actors to insincerity and hypocrisy, requiring that they suppress expression of unretouched opinions or feeling in favor of adopting a more socially pleasing façade. Etiquette can demand adherence to norms that are, sometimes rather obviously, culturally contingent or seemingly arbitrary. Etiquette can require that even the simplest endeavors be pursued circuitously, detouring practitioners away from straightforward efficiency by demanding they do what they do decorously. (Olberding 2015, 145)

From this we can discern at least four different meanings of "artificial" relevant to the discussion of manners, which can also be found in a standard dictionary definition of the term (Random House Webster's Unabridged Dictionary 2001, 119):

(1) We may use the term "artificial" to indicate that something is effortful or that it lacks spontaneity. The opposite of the term here is the way we use the term "natural" in saying that something comes naturally to someone (i.e., he does not have to use much effort to do it). We might then make the additional assumption that everything that is effortful or non-spontaneous is in some sense deficient. If we then add the idea that well-mannered behavior will often prove effortful, it becomes clear why we should consider manners as problematic. ${ }^{1}$

(2) "Artificial" can also be used to mean "false", "insincere", or "inauthentic". The assumption here is that our natural behavior has a positive quality, namely authenticity or sincerity, and that these qualities are lost through our focus on well-mannered behavior. Thus, for instance, well-mannered behavior often does seem to involve masking one's true feelings towards others and their actions.

(3) We can also understand "artificial" as simply meaning "non-natural". One might then further assume naturalness is a positive quality. This would be the case, for example, if we assumed that human nature and the behavior that directly springs from it may be changed for the worse through the installation of certain non-natural patterns and rules of behavior (artificial rules).

1 Zhuangzi's criticism of human activity (wei 偽) can be read along these lines. For such a reading see e.g., Lee 2005, 15-17. For a further discussion of naturalism in the Warring State Period, see Eno 1990, 138-43. 
(4) Lastly, the term "artificial" can be used to denote something arbitrary. Thus, in a different context, we can say that a given system of classification is artificial or that a particular distinction seems artificial. What we mean to say here is that the classification or distinction has no grounding in what is (objectively) given. Polite behavior will at least sometimes involve differentiations (such as when we host an event and greet the guest of honor before the others). Critics could claim that the distinctions made in polite behavior often lack any form of proper grounding.

If the alleged ethical value of manners is to be defensible, it seems one must have something to say about all four of these claims. This can take various forms, such as a direct rebuttal of the validity of the claim or some argument that manners do not in fact instantiate the property in question. In what follows, I will discuss two different strategies of dealing with the claims, one suggested by Kant and the other by Xunzi. As I will show, both authors answer the claims by making a suggestion as to the function of manners, which in turn also delimits the scope of what can count as well-mannered behavior.

\section{Kant's Concept of Manners}

Engaging with Kant when discussing the artificiality of manners may seem like a surprising choice. Indeed, in contrast to Xunzi, Kant does not give us a full-blown account of manners. Nevertheless, we do find some discussion on the importance of manners, in the course of which he portrays them as ethically relevant. The most prominent work in this respect is his Anthropology from a Pragmatic Point of View, which I will focus on in this paper. There, Kant begins his discussion of manners with a paragraph that delves right into the heart of the matter:

On the whole, the more civilized human beings are, the more they are actors. They adopt the illusion of affection, of respect for others, of modesty, of unselfishness, without deceiving anyone at all, because it is understood by everyone that nothing is meant sincerely by this. And it is also very good that this happens in the world. (Kant 2006, 42)

The passage appears baffling at first. Why should it be a good thing that we behave like actors, creating the illusion for others that we respect them and wish them well, when really we don't? And why would it make a difference ethically that everyone knows that we are only creating an illusion?

One suggestion that can be constructed on the basis of Kant's text is that the illusion in question is a necessary evil resulting from serious flaws in human nature. 
Kant discusses the question of whether man's nature is good or evil towards the end of the Anthropology. Here, he distinguishes two aspects of human nature: man's rational (intelligible) nature and his sensible nature. The intelligible nature allows us to recognize the moral law and act in accordance with it, and therefore Kant takes it to be good. He is clearly far less optimistic with respect to man's sensible nature. Thus he claims:

But experience nevertheless also shows that in him there is a tendency to actively desire what is unlawful, even though he knows that it is unlawful; that is a tendency to evil, which stirs as inevitably and as soon as he makes use of his freedom and which can therefore be considered as innate. Thus, according to his sensible character the human being must also be judged as evil (by nature). (Kant 2006, 229)

One can thus see man's sensible nature as a kind of obstacle that must be overcome. According to Kant this can be done, but only through an effortful process of cultivation and moralization (ibid. 1968, 324-5). He does not mention politeness in this part of the Anthropology. Nor does he give us a very detailed account of the moralization process here. Nevertheless, it does seem plausible to suggest that manners could be part of such a process, as they will often demand keeping our sensible nature in check, and arguably form an important basis for humans living together in a society, which Kant, in turn, does mention in his discussion of moralization (ibid., 324). ${ }^{2}$ Through these remarks Kant indirectly counters artificiality claims (1) and (3), i.e., the claims that manners are artificial in the sense of demanding effort, and in that of running counter to human nature. According to Kant, manners do indeed run counter to our sensible nature. However, because our sensuous inclinations are problematic anyway, this cannot be taken as the basis of an argument against politeness. Kant simply denies the claim that the whole of human nature is good and worthy of being preserved. Rather, it is only the intelligible part that must be upheld. And, with respect to this part of human nature, manners seem to play a bolstering instead of a destructive role. They are instrumental in letting rationality prevail against our problematic inclinations.

A similar strategy can also be applied for giving a Kantian answer with respect to the first artificiality claim. Kant simply denies that activity and effort are problematic qualities. Rather, according to his account, it is passivity on the side of our intelligible nature that is problematic. It is only the active countering of our problematic, sensible inclinations that makes us "worthy of humanity" (ibid., 325); this is also stressed

2 It is interesting to see that in the same passage Kant also heavily criticizes Rousseau for his pro-naturalism view of human nature (Kant 1968, 326-7). 
in Klemme 1999). Effort, insofar as it is guided by reason, must thus be seen as a positive trait, while passivity towards our sensible nature will incline us to act badly. In failing to take an active stance, we are responsible for the evil actions that ensue (Klemme 1999). Again, though Kant does not explicitly mention politeness, it does seem that we could see it as part of such an active endeavor guided by rationality.

Up to now I have focused exclusively on Kant's understanding of human nature as it is conveyed in his Anthropology. Taking Kant's other writings into account, and especially his Religion within the Boundaries of Mere Reason, gives us a different angle on human nature and the role of manners with respect to it (Kant 2003). ${ }^{3}$ In this work Kant explicitly rejects the sort of mixed view on human nature sketched above (DiCenso 2012; Wood 2014; Palmquist 2016; Kant 2003, 43). Rather than residing in our sensible nature, evil here is suggested to come about as a result of buman choice. Thus, as Wood explains, in this view:

Inclinations themselves, insofar as they do not originate from free choice, can never be evil. They become involved in evil only when they have been taken as incentives in a freely chosen maxim which is evil. And then it is this maxim that is evil, not the inclinations themselves. (Wood 2014,34)

Although our natural inclinations are not bad as such, we can still make a mistake by assigning a wrong role to them. We can furthermore be tempted to do so due to the strength of some of our inclinations and to the propensity to evil that Kant ascribes to humans. As has been noted in recent publications, we should not understand this as implying that human nature is in some sense bad. Rather a propensity, according to Kant, is an inclination that exists only in potential form at first but grows if it is nurtured by us through engaging in the related activities. Thus, according to Kant, the desire for alcohol in the alcoholic might exist as a mere potentiality, until the person has actually drunk alcohol. Only through such acts of nurturing do we arrive at strong habitual desires to seek out more experiences of the same kind, and there is thus an element of choice ingrained here (Stroud 2010, 642-3; Wood 2014, 50-51; Kant 2003, 34-39). ${ }^{4}$

3 In claiming that Kant is offering two competing interpretations of human nature in these two texts I follow Brandt (Brandt 1999, 483-5). As Brandt points out, it is not quite clear why the two positions diverge. As he suggests, it may be the case that Kant does not want to go into too much detail in the Anthropology and therefore settles for a position he does not deem fully correct. Otherwise, it may also be the case that he is in some sense rethinking his position. I leave the question of how these differences come about open, as nothing much depends on this issue for the purposes of this article.

4 I do not have the space to go into the details of Kant's exposition here, and am therefore skimming over some of its complexities. For an overview on the matter, see newer commentaries on this section (Palmquist 2016; Wood 2014; DiCenso 2012). 
Kant also assigns the (good) predisposition to us to follow the moral law. This predisposition cannot be lost, even if we continuously act badly. What we should aim for is to reinstate it to its "rightful place as the sole element influencing our moral choices" (Palmquist 2016, 128). And this, in turn, involves viewing our inclinations as irrelevant to these choices (ibid.). In requiring us to act as if we respect others (independent of our actual feelings), behaving politely can be an important part of such a reinstatement. We can thus say that (in spite of their differing discussions of human nature) manners can be assigned an important role in self-cultivation on the basis of both the Anthropology as well as Religion within the Boundaries of Mere Reason.

Kant does not only state that the illusion of benevolence created by politeness is a necessary evil for keeping our sensible nature in check or reinstating our good predisposition to its rightful place. Rather, he also claims that this illusion can-in the long run - turn into something real. Thus he explains: “(...) these signs of benevolence and respect, though empty at first, gradually lead to real dispositions of this sort” (Kant 2006, 44). In behaving politely, we start off by faking our respect for others, but over time we can acquire real respect by doing so.

Nevertheless, the fact that Kant suggests that "faking it" is permissible seems puzzling. As quoted, he claims that manners are "signs of benevolence and respect" (my emphasis). The talk of "signs" is rather vague here, but an earlier passage in the Anthropology suggests that Kant directly links the term with acts of communication. There he lists "signs of gesticulation" and "memetic signs" with language, letters, and "signs of social standing" as "arbitrary" as opposed to "natural signs" (Kant 2006, 85-86) and highlights their importance in interpersonal communication. Thus, by talking about well-mannered behavior as a sign, Kant is suggesting that politeness is a communicative, interpersonal act. But this gives rise to a problem. If we are engaging in an interpersonal act of communication and are intentionally being untruthful in this act, then one could suggest that we are lying. And it seems that even if a lie has positive results in the long run, it is nevertheless a morally problematic act.

The problem is all the more pressing for Kant, because in other places he suggests that lying is not permitted under any circumstances. As Korsgaard has pointed out, a reason for Kant's rigorous stance can be reconstructed from the so-called Formula of Humanity, which demands: "So act that you use humanity, whether in your own person or in the person of any others, always at the same time as an end, never merely as a means" (Kant 1998, 38). Humanity, in turn, is understood here as a specific capacity, namely the capacity to rationally determine our own ends (Korsgaard 1986; Kant 1998, 44). 
The problem about lying, according to Kant, is that we are putting others in a condition in which we are depriving them of the possibility to exercise that capacity, because those we deceive cannot possibly rationally assent to our action. As Korsgaard has highlighted, the issue comes up independently of whether the victim of the deceit knows what is happening. Thus, if we do not know we are being deceived, we cannot of course rationally assent to that act, as we do not know that this is what is happening. However, even, if we do know that we are being deceived, it is also not within our capacities to assent to the deceit, because in this situation there is no actual act of deceit (only a failed attempt to engage in such an act) (Korsgaard 1986).

Because of this rigorous rejection of the permissibility of lying, Kant cannot accept that manners are both ethically valuable and that they are a way of deceiving others. He needs to offer some other explication of what "empty" signs of "benevolence and respect" amount to, and in doing so he must show that we can rationally assent to each other's polite behavior (thus distinguishing it from the case of deceit).

The solution Kant offers lies in claiming that politeness is no act of deceit, but merely a benign illusion. Illusions, according to Kant, do not vanish once we are informed about the real circumstances, and in this they differ from deceit. Take the case of deceit again: Say Peter is a criminal who has just escaped from jail. Assume that he is pretending to be a policeman (by wearing a uniform, acting in ways associated with that role, and so on). If I do not know Peter, I will have the impression of seeing a real policeman. But as soon as I learn about his real identity my impression will change dramatically, and in a rather unpleasant way. This is different from the case of optical illusions, like the frequently discussed Müller-Lyer-illusion. Even once we learn that the two lines in this illusion are of equal length, the impression that they are unequal remains, and there is no unpleasantness in this at all.

Kant claims that politeness is an illusion, not a case of deceit, and as such, in his reckoning, the problems resulting from deceit vanish. We are not treated as mere means to an end by those that behave politely. We are not deceived, because we know that people are being friendly for show. Nevertheless, the behavior of those engaging in the illusion still has a positive effect on us, we continue to see this sort of behavior as appealing and worthy of emulation. The positive impression therefore remains. ${ }^{5}$

5 The distinction between deceit and illusion and its importance for understanding Kant's position on manners is highlighted by Frierson on whose discussion I rely here. Frierson also provides a detailed discussion of how illusions can motivate, which does much to explain and extend Kant's rather short comments on the issue (Frierson 2005). 
There is a further point that Kant makes concerning deceit, which deserves mention. While the positive impression that well-mannered behavior makes on others may lead them towards virtuous behavior, it is not clear from what has been said so far how it can also play a role in improving ourselves. Kant sees politeness as an act of "deceiving the deceiver in ourselves" (Kant 1968,151), and then goes on to claim that, again, this is not deceit proper, but actually the mere creation of an illusion. Thus one can say that Kant suggests there are two kinds of illusions at play here, an outer and an inner illusion created by manners. While it is clear why the outer illusion is relevant, one may wonder why this act of inner illusion should be necessary.

As Frierson has stressed, this idea is linked to Kant's take on the role that self-deceit plays for us. ${ }^{6}$ What Kant is implying is that while we are able to make rational choices independent of our inclinations, it is not always easy to do so. One reason for this is that at least some of our inclinations find a powerful ally in self-deceit. Kant gives us an example of such an act of self-deceit: he explains that we have an inclination towards being at ease, which leads us to staying largely passive. The self-deceit here is two-fold. First, we may have the impression that in remaining passive we are not doing anything evil, and are thus pursuing something that is morally good, while this is obviously not the case. Secondly, we are under the impression that we are avoiding unpleasant experiences (i.e., the experience of effort). But in doing so we are in fact conjuring up a most unpleasant state, namely boredom (Frierson 2005; Kant 1968, 151-2). Manners trick us into avoiding this problematic form of passivity by engaging us in pleasurable pursuits such as conversation, which, while seemingly effortless, nevertheless keeps our minds occupied and turns us into more cultured beings (Kant 1968, 152). ${ }^{7}$

Where does this leave us with respect to the artificiality claims? In his description of politeness, Kant counters claims (1), (2), and (3). In his replies he seems to be especially preoccupied with (2). This, in turn, seems to be the case because he understands manners as acts of tricking oneself and others. Through this, the problem of deceit looms large, an issue that Kant has to take seriously, in part because of his rigorous views on lying. Furthermore, it is striking that Kant does not seem to care much at all about the fourth artificiality claim, namely that manners involve arbitrary differentiations. This too is no accident. As explained earlier, Kant understands politeness as a sign of benevolence and respect. According to Kant, respect is something we owe to everyone, simply because they are persons.

6 For a further discussion of self-deceit, its relation to passions and importance for Kant's position on human nature, see Wood (Wood 2014, 44)

7 For a more detailed interpretation that also explores the different discussions on self-deception, which Kant offers in his Lectures on Antbropology, again see Frierson's analysis (Frierson 2005). 
Manners, from this perspective, are thus not connected to any sort of distinction between people on the basis of achievement or rank, but rather just expressing what is owed to all persons qua persons. Therefore, there is no need to worry about them potentially containing arbitrary kinds of differentiation. The fourth artificiality claim thus does not seem threatening to Kant's approach, because he denies that manners have a differentiating function. ${ }^{8}$

\section{Xunzi's Understanding of Artificiality}

While manners and politeness lie at the periphery of Kant's philosophy, they are at the very heart of Xunzi's thinking. In saying so, one should be aware of the fact that Xunzi uses the term $l i$ (禮), and thus does not talk about manners in isolation, but rather also about rituals, religious customs, and so on. In spite of this broader notion, I will only discuss manners here. Often, $l i$ (禮) is translated as “ritual". To avoid confusion, I will replace this with the original term $(l i$ 禮) in the translations cited.

Central for Xunzi's position on manners is his view of human nature. Thus, at the very beginning of the Discourse on Ritual he writes:

From what did li (禮) arise? I say: Humans are born having desires. When they have desires but do not get the objects of their desire, then they cannot but seek some means of satisfaction. If there is no measure or limit to their seeking, then they cannot help but struggle with each other. If they struggle with each other then there will be chaos, and if there is chaos then they will be impoverished. The former kings hated such chaos, and so they established $l i$ (禮) and $y i$ (義) in order to divide things among people, to nurture their desires, and to satisfy their seeking. (Hutton 2014, 201)

In this passage Xunzi indirectly seems to be tackling the third artificiality claim. He does so by applying a strategy that is, on first glance, similar to Kant's. Like Kant, Xunzi highlights certain negative aspects of human nature, as well as the disastrous effects uncontained expressions of our naturally given desires may have. In the passage cited, Xunzi stresses the social instead of the individual consequences of leaving our desires uncontained. He might therefore be read as worrying not so much that the individual may act in morally problematic ways, but rather that social order cannot be upheld if everyone were to focus on their own desires.

8 In the current literature, Sarah Buss presents a largely Kantian view, which also puts strong emphasis on this notion of respect (Buss 1999). 
This, however, does not mean that Xunzi focusses exclusively on these social consequences. He does not only speak of society being chaotic; he thinks that this can also be a feature of individuals. ${ }^{9}$ As such, in his reflections on human nature he claims the following:

Thus, crooked wood must await steaming and straightening on the shaping frame, and only then does it become straight. Blunt metal must await honing and grinding, and only then does it become sharp. Now since people's nature is bad, they must await teachers and proper models, and only then do they become correct. They must obtain $l i$ (禮) and $y i$ (義), and only then do they become well-ordered. (ibid., 248)

This passage may seem puzzling. What does it mean that people are "well-ordered"? In what sense is a well-ordered person different from a badly ordered one? Xunzi certainly does not believe that becoming a well-ordered person involves extinguishing one's desires. As he puts it:

All those who say that good order must await the elimination of desires are people who lack the means to guide desires and cannot handle the mere having of desires. All those who say good order must await the lessening of desires are people who lack the means to restrain desire and cannot handle abundance of desires. (ibid., 243) ${ }^{10}$

Rather than being exterminated, desires must be brought under control in the sense of people not automatically following any desire they have. This is difficult, because we have the natural tendency to act on them. ${ }^{11}$ Nevertheless, our psychological makeup also opens other options. Namely, we are also able to reflect on our desires through some higher order capacity, i.e. through our intellect ( $x$ in 心). It is through this capacity that we decide which desires we should act upon. ${ }^{12}$ When we fail to put this capacity to use, we remain internally disordered.

9 The general focus on order in the Xunzi is also highlighted by Machle. Machle stresses that Xunzi mostly uses the term zhi 治, which he translates as: "to manage', 'to put into order', 'to heal", instead of zheng 政, which he understands as being connected to "government' or 'to correct by law, force, or sanctions"'. (Machle 1993, 47)

10 In other sections of the Xunzi we do, however, find the idea that we can shape and thus change our "inborn dispositions" through practice. (See Hutton 2014, 249).

11 This aspect of Xunzi's theory is often overlooked, but has recently been stressed by Chenyang Li (Li 2011).

12 For an interpretation along these lines see Lee 2005, 48-51. 
The idea of there being such a thing as an "internal disorder" becomes clearer when we reflect on what it would mean to act on any desire we have without further reflection. If we did so, our overall pattern of action would turn out incoherent. To give an example: we may have the desire to remain healthy, but also a desire to eat large quantities of fatty foods and smoke cigarettes. Clearly, these desires cannot all be fulfilled at the same time, and we must choose among them if we are to achieve any of our goals. If we decide that staying healthy is the desire we should follow, then this gives our actions a distinct direction and stops them from oscillating between healthy and unhealthy ways of acting. ${ }^{13}$

This reading does not imply that man innately has both good and bad qualities or good and bad desires. Rather, the suggestion is that Xunzi does not take the desires in themselves to be the problem. It is not, for instance, that we are beset by ethically problematic desires and that we therefore continuously strive for what is bad. It is rather that blindly following our desires without any further reflection leads to both inner and outer turmoil and chaos. It is this chaotic state that Xunzi condemns. This strong disapproval lets him declare human nature to be bad, because it lacks standards that allow for a proper ordering of desires, a step that is crucial if we are to avoid disorder. ${ }^{14}$

So far, so good, but why should we think that manners are of relevance for creating order at the individual level? One way in which manners are essential, according to Xunzi, is that they give us some standard on the basis of which we can decide which of our desires we should follow. What we thus need is some understanding of which of our desires are permissible ( $k e$ 可) and which are not (Hutton 2014, 243). Manners provide us with a standard against which we can judge the appropriateness of our desires, and on the basis of which we can decide which of our desires to pursue.

We can now see the difference between Xunzi's and Kant's conception of human nature and how it figures in their reflections on the artificiality of manners. While Kant focusses on the fact that we may be tricked into pursuing what is not allowed

13 I am picking up on a very similar interpretation of the passage suggested by A. C. Graham. Graham gives us a very fitting description here: "For Hsün-tzu human nature is bad in that desires are anarchic, in conflict both within and between individuals" (Graham 1989, 248). For a further interpretation along similar lines see Stroud's text on Xunzi and Kant (Stroud 2010).

14 My interpretation here owes much to Chenyang $\mathrm{Li}$ ( $\mathrm{Li} 2011$ ), who also stresses the fact that desires cannot in themselves be declared as moral or immoral. He distinguishes between the talk of badness in a world that is still devoid of any standards, and in a world in which the standards are already in place. He sees Xunzi's talk of human nature as bad as meaning that it is naturally bad (i.e. bad in the sense that it inhibits the satisfaction of our desires). Once the standards are put into place, we can look back at this point in time and declare human nature as bad from our current (moral) standpoint (ibid., 60). 
in spite of knowing better, Xunzi stresses the chaos into which our uncontrolled desires may lead. Xunzi does not claim that in blindly following our desires we are acting against better knowledge. Initially, this cannot be the case, because in the state of nature he presumes, there is no standard according to which we could know better.

Xunzi thus suggests that without $l i$ there are no standards which allow us to fend off the anarchy into which our uncontrolled desires lead. The disorderly nature (not the inherent badness) of our desires as well as our inclination to blindly follow them is what is bad about them, and this is what makes it necessary to install standards which permit us to weigh our desires, sort them into good and bad, important and unimportant, and decide upon which of them to act. Xunzi's reflection on human nature can also be understood as an argument against the first artificiality claim, namely the idea that manners disrupt our spontaneous ways of acting. ${ }^{15}$ This indicates that Xunzi, like Kant, thinks that deliberate effort is needed to make up for the problematic aspects of human nature. This also becomes clear in a further passage, where Xunzi explains: "Thus, I say that human nature is the original beginning and the raw material, and deliberate effort is what makes it patterned, rendered, and exalted" (Hutton 2014, 210). Deliberate effort is needed to bring order to our own nature and to the social world that surrounds us. ${ }^{16}$

Xunzi takes manners to be central for the creation of individual and social order, because they allow us to differentiate. In the social world, these differentiations take the form of distinctions between different social ranks. He thus explains: "In $l i$ (禮), noble and lowly have their proper ranking, elder and youth have their proper distance, poor and rich, humble and eminent, have their proper weights" (ibid., 84-85). At the same time, he also suggests that on the individual level $l i$ allows us to differentiate between what is permissible and impermissible, and also between other aspects such as good fortune and bad fortune which may result from our desires (ibid., 245). These differentiations in turn allow us to adjust our conduct appropriately.

Here, a crucial difference between Kant and Xunzi comes into view. While Kant stresses the communicative and activating function of manners, Xunzi's concern is with manners in so far as they allow us to bring order to an otherwise chaotic world. With this focus on manners as crucial for creating social and individual

15 For a recent publication stressing this aspect of the Xunzi, see Puett and Gross-Loh (Puett and Gross-Loh 2016).

16 The fact that both Kant and Xunzi stress the importance of human activity with respect to our desires and inclinations is also stressed by Stroud (Stroud 2010). 
order, artificiality claim number four (the claim that hardly plays any role in Kant's theory) comes to the forefront of our attention. Because Xunzi understands manners as creating order both on the individual and the social levels, he must rebut the criticism that the order thus constructed has no grounding in reality.

To counter this line of criticism, Xunzi must insist that it is not any sort of ordering that will do. What must be installed in society and the individual is rather the 'right kind' of order, and this is supposedly an order that has some grounding in objective facts. Thus Xunzi claims: "One's virtue must have a matching position, one's position must have a matching salary and one's salary must have matching uses" (Hutton 2014, 85). Xunzi stresses that one's position in the social world is not without grounding in one's own character and achievements, but rather ideally has a basis in one's own character and virtues.

As Janghee Lee has elegantly shown, this position can be combined with Xunzi's view on the rectification of names. Lee suggests that names in Xunzi are conventional, in the sense that they are agreed upon by the people using them, but are nevertheless not to be understood as totally arbitrary. They cannot be, because Xunzi takes care to stress that good names (shanming 善名) should not be at "odds with the things" (bufu 不拂) (Knoblock 1994, $22.2 \mathrm{~g}$ ). ${ }^{17}$ Lee stresses that there is an analogy here with measurements (an idea also found in the Xunzi). While the metric unit we establish in a society is conventional, no metric system we develop should be at odds "with the world" (Lee 2005, 61-62). In a similar vein, we might say that manners are conventional, but not arbitrary, because the differences they establish must be grounded in reality.

Going back to the original discussion of different kinds of artificiality arguments, we can see that Xunzi tries to counter arguments (1), (2), and (4). But what about argument (3), the claim that manners are artificial in the sense of being deceitful or insincere?

In my view Xunzi is not concerned with this aspect. There is no detailed, explicit discussion of whether manners must always present us with a truthful expression of our inner feelings and intentions. And, indeed, the omission makes sense in view of what I have presented thus far. One could suggest that Xunzi is primarily concerned with the ordering function of manners and not with the

17 Note that I am using Knoblock's translation here. Hutton sees the passage as implying that the names should "not conflict" with one another (Hutton 2014, 239). I think that the difference between the two translations is not as great as it may seem at first. Thus, one would generally assume that names that conflict with one another are also at odds with the world. Furthermore, it seems that while there could be internally coherent systems of naming that have no basis in reality whatsoever, these would be extremely difficult to uphold. As such, it does seem plausible that Xunzi has both internal coherence as well as external congruence in mind. 
communicative one, and therefore that inauthenticity and insincerity are not issues he must deal with.

Unfortunately, however, the issue is not quite as clear cut. Indeed, there are some sections of the Xunzi where the author does seem to associate some form of communicative function with $l i$, and perhaps even seems to hint at issues connected to their potential insincerity. In what follows I will briefly discuss the most striking of these passages, and show why they do not necessarily commit us to assuming that Xunzi does assign a communicative function to $l i$.

Some newer interpretations of the Xunzi stress the importance of make-believe in the discussion on burial rituals. ${ }^{18}$ For example, Xunzi claims that in funeral rites one treats the dead "as if still alive" (Hutton 2014, 211). Doesn't this "as-if" way of acting suggest that there is, after all, some form of pretense ingrained in the rites themselves? And how does this fit together with the idea that $l i$ must not be at odds with the things? In treating someone dead as though he were still living aren't we deviating from this norm?

Though the observation that there is an as-if mode of acting is adequate, these are not the right conclusions to draw. Amy Olberding has suggested that Xunzi's discussion of funeral rites is due to a particular dilemma we encounter when facing death. On the one hand, the dead person is, for us, still a person, a person that we grieve for. On the other hand, the dead person is also a mere thing, a slowly decaying corpse. Both perspectives are bound up with different dispositions: the disposition to take care of the person and the disposition to flee from the corpse. Xunzi sees burial rites as necessarily paying heed to both aspects (O1berding 2015). It is thus necessary that the dead person is treated both as a person and as a corpse, and that the rituals in question reflect this. We can thus say that in treating someone dead as if he were still alive we are not acting at odds with the things, but rather very much in line with them. This double perspective is reinforced through the fact that, while dressing the person as if he were still alive, there are subtle differences that are put in place such as not securing the hat with a hairpin and not fastening the belt (Hutton 2014,211). This can be understood as an acknowledgement that we are not dealing with a person in the full sense of the term anymore, namely we are not dealing with someone who partakes in social interactions. The make-believe we are engaged in is not really a case of deception

18 Berkson highlights the frequent usage of the term ( $r u$ 如) in the Xunzi and claims: "Ritual participation can be seen, perhaps, as a form of sophisticated pretending or play, artificial and invented, yet necessary for conflicted and fragile beings such as ourselves.” (Berkson 2014, 120). Note that Berkson also does not assume that we are deceived, but suggests that we are fully aware of what is going on. I am not rejecting Berkson's interpretation, but rather only a conclusion one might be tempted to draw from it. 
(nor a case of illusion, in Kant's sense of the term), but rather an acknowledgement of our complicated relationship with death.

There are some further aspects of Xunzi's discussion of $l i$, which also suggest an interest in their communicative function. Olberding thus suggests that manners are supposed to beautify our behavior. This beautification is necessary, because the "open display of our base needs and interest" may well generate aversion in others and therewith undermine human cooperation (Olberding 2015, 157). On her reading of the Xunzi, manners are needed to make our behavior sufficiently attractive to others to allow for cooperation. But this again seems to bring up the following problem: Doesn't beautification amount to merely hiding what is base about ourselves? And, again, isn't this an act of deceit? ${ }^{19}$

I don't think this is the case. As I have stressed before, I take Xunzi's li to be a standard which allows us to choose non-arbitrarily among our desires. Choice here will mean putting some desires into action while leaving others aside. And this is, in turn, a crucial step for liberating us from a situation in which we must blindly follow any desire that happens to crop up. But in this act of choice there is no room for deceit. We cannot "just pretend" to follow one desire or another. Rather, in choosing a desire we act on it and outwardly express it. Expression and action are not additional acts, but part of the choice itself. This also becomes clear in the following passage:

$L i$ (禮) cuts off what is too long and extends what is too short. It subtracts from what is excessive and adds to what is insufficient. It achieves proper form for love and respect, and it brings to perfection the beauty of carrying out $y i$. (...) Thus, when the change in disposition and appearance are sufficient to differentiate good fortune and ill fortune and to make clear the proper measure of noble and lowly, close relations and distant relations, then $l i$ (禮) stops. To go beyond this is vile, and even should it be a feat of amazing difficulty, the gentleman will still consider it base. (...) It is not the proper patterning of $l i$ and $y i$, it is not the true disposition of a filial son. It is rather the behavior of one acting for ulterior purposes. (Hutton 2014, 210)

Changes in disposition are only supposed to make the differentiations in line with $l i$ and $y i$; our outward expressions are simply an expression of these differentiations. There is no room here for other motives. Such other motives and intentions can only come up when we are no longer acting in line with $l i$. As a consequence, it

19 This is not Olberding's explicit position, but rather only a conclusion one could (but need not) draw from her description of the beautifying function of manners. 
seems that deceit and illusion are unrelated to $l i$. One can thus conclude that the claim that manners are artificial in the sense of giving rise to insincere behavior is irrelevant when viewed from Xunzi's position.

\section{Implications for a Theory of Manners}

The different versions of the artificiality claim discussed above highlight potentially problematic aspects of manners, and so pose a threat to the claim that manners are ethically relevant. Both Xunzi and Kant counter this claim. From a systematic perspective, we can say that they do so by employing a similar mix of strategies. They respond first of all by giving an account of human nature and effortful action which indicates that manners can be ethically relevant in spite of being effortful, and despite (at least in the case of Xunzi and Kant's discussion in the Anthropology) their running counter to some aspects of human nature. However, they also respond to the artificiality claims by giving a specific analysis of the function of manners. While Kant focusses on the communicative function of manners, Xunzi assigns them the function of installing a non-arbitrary social order. Through this step both authors indirectly block one specific sort of artificiality claim (i.e., the claim that they are deceptive in the case of Xunzi, and the claim that they install an arbitrary social order in the case of Kant).

When considered from a systematic point of view, this step is not unproblematic. From an everyday perspective, it seems that manners can be both expressions of an egalitarian type of respect (a type of respect we owe to everyone independent of their social standing) and a means of constituting a specific social order, an order that will also include certain hierarchical elements (i.e., putting someone above or below us in social hierarchy). And it also seems that, properly understood, both aspects are ethically relevant. I seem to be at fault, for example, when jumping the queue at a local coffee shop, because I fail to pay due respect to those others waiting in line. ${ }^{20}$ But I equally seem at fault if I fail to pay due respect to a legitimate guest of honor at an official dinner I am hosting, where "legitimate" indicates the guest is truly deserving of the honor. Both Kant and Xunzi thus limit the scope of manners and analyze their function in a way that leads them to ignore one of these central aspects instead of acknowledging its relevance.

There are various ways in which one can respond to this issue. At first glance, it may seem as if the easiest solution lies in denying that both authors are indeed right. That is, we could construct some argument for why we must either be

20 I take this example from Karen Stohr (2012). 
Kantians or Xunzians on the issue in question. In my view, however, this is not a very promising avenue. A brief look at our everyday way of speaking suggests both authors are saying something fundamentally right and worthy of attention. So, prima facie, we should focus on the ways in which the two fundamental insights could be combined. There are two ways in which we might do so. We can either assume that what we call 'manners' in the everyday sense of the term actually consists of (at least) two different sets of conventional rules with different functions: one expressing egalitarian respect and one assisting in building a hierarchical social order. Or we can assume that well-mannered behaviour always consists in expressing respect towards others as persons, and that additionally some cases of well-behaved interaction assist in building a well-ordered society. Independently of which option we choose, it seems we must find some way of combining both Kant's and Xunzi's insights to arrive at a full-blown picture of manners and their functions.

\section{Conclusion}

To conclude the paper, let me briefly sum up the main line of argument. I suggested that there are different artificiality claims voiced in criticisms of manners: manners can thus be characterized as effortful, deceitful, contrary to human nature, and arbitrary, depending on the notion of artificiality one has in mind.

Both Kant and Xunzi share some basic views on manners, and therefore respond to some of these claims in a similar fashion. Specifically, they agree manners may function to counter the more problematic aspects of human nature. Therefore, both highlight these features and argue against the notion that human nature is good in its own right. For both of them manners present an effortful but worthwhile means of self-cultivation.

Nevertheless, there are also crucial differences between the two: Kant has a view of manners that stresses their communicative function and their egalitarian aspects. Manners are signs of a type of respect, which is owed to all persons independent of social rank, virtue, and so on. These aspects demand that Kant reflects on the potential deceitfulness of manners. But they also relieve him of the need to argue against the claim that manners install an arbitrary social order. Xunzi, on the other hand, focusses on the individual and social order established through manners. Therefore, he is hardly concerned with their potential to deceive and much more with the threat of their installing a merely arbitrary order.

I concluded the paper by suggesting that both approaches are insightful in their own right. Nevertheless, both accounts are problematic in the sense that they 
limit the scope of manners in ways that are inconsistent with our everyday usage of the term. I thus suggested that we should aim at combining the two views to arrive at a plausible response to the artificiality claims and a full-blown account of manners.

\section{References}

Berkson, Mark. 2014. "Xunzi's Reinterpretation of Ritual: A Hermeneutic Defense of the Confucian Way." In Ritual and Religion in the Xunzi, edited by T. C. Kline III and Justin Tiwald, 107-32. Albany: SUNY Press.

Brandt, Reinhard. 1999. Kommentar zu Kants Anthropologie in pragmatischer Hinsicht. Hamburg: Felix Meiner Verlag.

Buss, Sarah. 1999. "Appearing Respectful: The Moral Significance of Manners." Ethics 109: 795-826.

DiCenso, James. 2012. Kant's Religion within the Boundaries of Mere Reason: A Commentary. Cambridge: Cambridge University Press.

Eno, Robert. 1990. The Confucian Creation of Heaven: Philosophy and the Defense of Ritual Mastery. Albany: State University of New York Press.

Frierson, Patrick. 2005. “The Moral Importance of Politeness in Kant's Anthropology." Kantian Review 9: 105-27.

Graham, A. C. 1989. Disputers of the Tao: Philosophical Argument in Ancient China. Chicago, La Salle: Open Court.

Hutton, Eric. 2014. Xunzi: The Complete Text. Princeton University Press.

Kant, Immanuel. 1968. Anthropologie in pragmatischer Hinsicht. Kants Werke. Akademie Textausgabe VII. Berlin: Walter de Gruyter.

- 1998. Groundwork of the Metaphysics of Morals. Translated and edited by Mary Gregor. Cambridge: Cambridge University Press.

- 2003. Die Religion innerbalb der Grenzen der bloßen Vernunft. Hamburg: Meiner.

- 2006. Anthropology from a Pragmatic Point of View. Translated and edited by Robert B. Louden. Cambridge: Cambridge University Press.

Klemme, Heiner. 1999. "Freiheit des Willens und Herrschaft des Bösen: Kants Lehre vom radikalen Bösen zwischen Moral, Religion und Recht.” In Aufklärung und Interpretation: Studien zu Kants Philosophie und ibrem Umkreis, edited by Heiner Klemme, Bernd Ludwig, Michael Pauen, and Werner Stark, 125-51. Würzburg: Königshausen und Neumann.

Knoblock, John. 1994. Xunzi. A Translation and Study of the Complete Works Vol. 3. Stanford, California: Stanford University Press.

Korsgaard, Christine. 1986. “The Right to Lie: Kant Dealing with Evil.” Philosophy and Public Affairs 15 (4): 325-49. 
Lee, Janghee. 2005. Xunzi and Early Chinese Naturalism. Albany: State University of New York Press.

Li, Chenyang. 2011. "Xunzi on the Origin of Goodness: A New Interpretation." Journal of Chinese Philosophy Supplement to Volume 38: 46-63.

Machle, Edward J. 1993. Nature and Heaven in the Xunzi: A Study of the Tian Lun. Albany: State University of New York Press.

Olberding, Amy. 2015. "From Corpses to Courtesy: Xunzi's Defense of Etiquette." The Journal of Value Inquiry 49 (1-2): 145-59.

—. 2016. "Etiquette: A Confucian Contribution to Moral Philosophy." Ethics 126 (January): 422-46.

Palmquist, Stephen R. 2016. Comprehensive Commentary on Kant's Religion within the Boundaries of Bare Reason. Chichester: Wiley Blackwell.

Puett, Michael, and Christine Gross-Loh. 2016. The Path: A New Way to Think About Everything: Viking.

Random House Webster's Unabridged Dictionary. 2001. 2nd ed. New York, Toronto, London, Sydney, Auckland: Random House.

Stohr, Karen. 2012. On Manners. New York, Abingdon: Routledge.

Stroud, Scott R. 2010. "Desire and the Project of Moral Cultivation: Kant and Xunzi on the Inclinations." In Cultivating Personhood: Kant and Asian Philosophy, edited by Stephen R. Palmquist, 639-52. Berlin, New York: Walter de Gruyter.

Wood, Allen W. 2014. “The Evil in Human Nature." In Kant's Religion within the Boundaries of Mere Reason: A Critical Guide, edited by Gordon Michalson, 31-57. Cambridge: Cambridge University Press. 